\title{
STRUKTURALNA ANALIZA MOLEKULE VODE I NJENA FIZIKALNA SVOJSTVA
}

\section{STRUCTURAL ANALYSIS OF A WATER MOLECULE AND ITS PHYSICAL PROPERTIES}

\author{
Elvis Žic, Ivana Gobin ${ }^{* *}$, Lara Batičić ${ }^{* *}$
}

\begin{abstract}
Sažetak
Voda $\left(\mathrm{H}_{2} \mathrm{O}\right)$ je polarni anorganski spoj, koji je na sobnoj temperaturi tekućina bez okusa i mirisa, gotovo bezbojna. Količinski je daleko najzastupljeniji spoj na Zemlji i među rijetkim je tvarima koje na Zemljinoj površini postoje u krutoj, tekućoj i plinovitoj fazi. Kao relativno jednostavan kemijski spoj, opisana je kao „univerzalno otapalo“ ili „otapalo života“. Ujedno je i treća najzastupljenija molekula u Svemiru. Molekule vode međusobno tvore snažne vodikove veze, što joj definira specifična fizikalna i kemijska svojstva. Vodikove veze zaslužne su za mnoga jedinstvena svojstva vode, poput anomalije vode (činjenice da je kruti oblik - led - manje gustoće od tekuće vode), relativno visoke temperature vrenja $\left(100{ }^{\circ} \mathrm{C}\right) \mathrm{i}$ velikog toplinskog kapaciteta, što su ključni preduvjeti za očuvanje života na Zemlji. Voda je amfoterna molekula, što znači da može pokazivati svojstva i kiseline i lužine, ovisno o kemijskom okruženju u kojem se nalazi. U radu je provedena strukturna analiza molekule vode i njenih najvažnijih fizikalnih svojstava, s naglaskom na anomaliju vode. Jedno od važnih fizikalnih svojstava tekućine, a koja uvelike utječu na naš okoliš, je niska gustoća leda u odnosu na tekuću fazu vode te fenomen negativnog koeficijenta ekspanzije hladne vode. Također je opisano rješenje nuklearne Schrödingerove jednadžbe, koja daje informacije o unutarnjim gibanjima (vibracijama i rotaciji) molekule vode.
\end{abstract}

Ključne riječi: struktura molekule vode, fizikalna svojstva vode, termička svojstva vode, dimer, Schrödingerova jednadžba, P-V-T dijagram

\footnotetext{
Sveučilište u Rijeci, Građevinski fakultet, Radmile Matejčić 3, 51000 Rijeka E-mail: elvis.zic@uniri.hr

** Sveučilište u Rijeci, Medicinski fakultet, Braće Branchetta 20/1, 51000 Rijeka E-mail: \{ivana.gobin, lara.baticic\}@medri.uniri.hr
} 


\begin{abstract}
Water $\left(\mathrm{H}_{2} \mathrm{O}\right)$ is a polar inorganic compound that is almost colorless at room temperature. It is by far the most common substance on Earth and among very few substances, which exists on the Earth's surface as a solid, liquid and gaseous substance. As a relatively simple chemical compound, it has been described as a "universal solvent" or "solvent of life". It is also the third most common molecule in the Universe. Water molecules form strong polar hydrogen bonds with each other, which, in turn, define its specific physical and chemical properties. Hydrogen bonds are responsible for many unique properties such as the anomaly of water (the fact that its solid form, the ice, is less dense than the liquid form), a relatively high boiling point $\left(100{ }^{\circ} \mathrm{C}\right)$ and a high heat capacity. Water is an amphoteric molecule, which means that it can show properties of both acids and alkaline solutions, depending on the chemical environment. In this paper, a structural analysis of a water molecule and its most important physical properties was carried out in detail with regard to its anomalies. One of the important physical properties of a liquid that strongly influences our environment is the low density of ice in relation to the liquid phase of water, and the phenomenon of the negative expansion coefficient of cold water. This work also describes the solutions of the nuclear Schrödinger equations, which provide information about the internal motions (vibrations and rotations) of a water molecule.
\end{abstract}

Key words: structure of the water molecule, physical properties of water, thermal properties of water, dimer, Schrödinger equation, $P$-V-T diagram

\title{
1. Uvodno
}

Čudesna voda, njene prirodne ljepote i obilježja su kroz vjekove nadahnjivala mnoge pjesnike, slikare, skladatelje, filozofe i znanstvenike. Krajem 18. stoljeća Lavoisier i Priestley prikazuju vodu kao „mješavinu“ elemenata [1,2]. U 16. stoljeću Leonardo da Vinci objavljuje svoju knjigu „Del moto e misura dell'acqua“, u kojoj opisuje sofisticirana istraživanja fizikalnih svojstava vode. Vrlo je teško razjasniti točnu ulogu ili uloge vode u složenoj kemiji životnih procesa. Voda djeluje kao otapalo za polarne spojeve te čini dvije trećine ljudskog organizma [1,3]. Sudjeluje u četiri velike skupine biokemijskih reakcija: oksidaciji, redukciji, kondenzaciji i hidrolizi. Oksidacija vode predstavlja jednu od važnih komponentnih reakcija fotosinteze. Shematski se oksidacija vode može napisati kao $2 \mathrm{H}_{2} \mathrm{O}=$ $\mathrm{O}_{2}+4 \mathrm{H}^{+}+4 \mathrm{e}^{-}$, odnosno kao reakcija $4 \mathrm{H}_{2} \mathrm{O}=\mathrm{O}_{2}+4 \mathrm{H}^{+}+2 \mathrm{H}_{2} \mathrm{O}+4 \mathrm{e}^{-}[4,5]$.

Fizikalna svojstva vode imaju važnu ulogu $u$ evoluciji. To se najuvjerljivije može ilustrirati usporedbama vode i zraka kao prirodnog okruženja svih živih bića. Svojstva koja su imala najveći utjecaj na razvoj života uključuju gustoću (težinu, tlak, dinamiku fluida), viskoznost, difuziju, toplinska i električna svojstva, površinsku napetost i širenje 
svjetla i zvuka. Izvanredne „zagonetke“ upravljanja vodama u biljnom svijetu uključuju pitanja poput kako voda dospijeva na vrh stabla i koje su sile koje proizvode gibanje vode unutar biljnih stanica i ksilema i floema netaknutih biljaka? Dvije abnormalnosti gustoće slatke vode su njena nemonotonska ovisnost o temperaturi i njeno smanjenje pri smrzavanju. Dobro je poznato kako je najveća gustoća vode na $4^{\circ} \mathrm{C}$, no manje je poznato da se morska voda tipične slanosti od $35 \mathrm{~g} / \mathrm{kg}$ razlikuje od slatke vode po tome što temperatura maksimalne gustoće leži ispod točke smrzavanja. Stoga je u oceanu najhladnija voda najgušća voda, a gustoća oceanske vode je pod utjecajem dubine (tlaka) i slanosti, koji utječe na uzgon vodenih organizama [6]. Upravo iz gore navedenih razloga, cilj i motivacija ovog rada je bio približiti široj populaciji važnosti pojedinih anomalija vode u pogledu njene strukture i dinamike kretanja na sveopći značaj na planeti Zemlji i procese koji se na njoj svakodnevno odvijaju.

\section{Svojstva vode i njene karakteristike}

Voda ima molekulsku formulu $\mathrm{H}_{2} \mathrm{O}$, odnosno sastoji se od dva vodikova atoma i jednog atoma kisika povezanih kovalentnim vezama. Može biti opisana i kao $\mathrm{HOH}$, s vodikovim ionom $\mathrm{H}^{+}$vezanim za hidroksidni ion $\mathrm{OH}^{*}$. Pri normalnim uvjetima se kod vode tekuća i plinovita faza nalaze u dinamičkoj ravnoteži. Na sobnoj temperaturi voda je gotovo bezbojna, bez okusa i mirisa [7]. Voda (Aqua dihidrogen monoksid) postoji u mnogim oblicima, u čvrstom stanju poznata je kao led koji može imati nekoliko kristalnih oblika, a ultra brzo hlađena voda može prijeći u amorfno stanje. U plinovitom stanju, voda je definirana kao vodena para. Iznad kritične temperature (647 K i 22,064 MPa) voda se nalazi u superkritičnim uvjetima, kada molekula vode čini skupinu molekula koje se ponašaju kao tekuća faza i koje lebde u parnoj fazi $[1,8]$. Teška voda je voda u kojoj je atom vodika isključivo zastupljen kao izotop deuterija $\left(\mathrm{D}_{2} \mathrm{O}\right)$. Po kemijskim i fizikalnim karakteristikama je skoro identična „običnoj“ vodi.

Voda je sveprisutna supstanca, pronađena u međuzvjezdanim oblacima u našoj galaksiji te Mlječnom putu. Vjeruje se da vode ima u znatnim količinama i u ostalim galaksijama jer su njeni sastojci vodik i kisik među najrasprostranjenijim elementima u Svemiru [2]. Nadalje, voda se može naći i u kometama, planetama i njihovim prirodnim satelitima. U tekućem obliku, voda je poznata samo na Zemlji, iako postoje prilično jaki dokazi da vode ima ispod površine Saturnovog mjeseca Enceladu [1]. Voda je prisutna u atmosferi u obliku tekućine i pare, odnosno u podzemlju u obliku podzemnih voda. U normalnim uvjetima voda vrije na $100{ }^{\circ} \mathrm{C}$, no postoje i prirodni uvjeti u kojima voda vrije i na $400{ }^{\circ} \mathrm{C}$ (voda pregrijana vulkanskom aktivnošću na dnu oceana) ili na jedva $70{ }^{\circ} \mathrm{C}$ (na vrhu Mont 
Everesta). Kao kemijsko otapalo, voda se koristi u mnogim industrijskim procesima i strojevima, poput parnih turbina i izmjenjivača topline.

Led u vodi, kao kruta faza, umjesto potonuća pliva na površini svoje tekuće faze (gustoća leda je manja od gustoće tekuće vode). Ova „anomalija“ vode je od velike važnosti. Kada se hladi sobnom temperaturom, gustoća vode raste (volumen se smanjuje). Međutim, na $4{ }^{\circ} \mathrm{C}$ gustoća vode doseže maksimum (Slika 1.). Daljnjim hlađenjem od $4{ }^{\circ} \mathrm{C}$ do točke smrzavanja, gustoća počinje ponovno opadati. Takvo ponašanje vode povezano je $\mathrm{s}$ kristalnom strukturom običnog leda, poznatog kao led Ih $[9,10]$. Voda ima nekoliko različitih čvrstih faza, od kojih su neke gustoće veće od tekućih (npr. amorfne vodene faze). Vodikove veze postoje i u čvrstom i u tekućem stanju. U tekućem stanju, zbog toplinskog gibanja, vodikove veze se neprestano grade i razgrađuju. U čvrstom stanju, molekula vode tvori dvije vodikove veze, koje kemijskim vezama formiraju tetraedar usmjeren na atom kisika. U tekućoj fazi se takva "terahera“ formira i urušava, što rezultira činjenicom da su atomi kisika nešto bliži jedni drugima u odnosu na realnu kristalnu rešetku. Tako se voda širi kada se smrzne jer se pri stvaranju kristalne rešetke atomi kisika odmiču jedan od drugog u nastojanju da formiraju pravilne tetraedre [9,11]. Voda (i led) su dobri toplinski izolatori, a prvi slojevi leda na površini vodenih masa usporavaju smrzavanje donjih slojeva s obzirom da se s njima ne miješaju zbog manje gustoće. Pri trojnoj točki vode, u ravnoteži su sve tri faze: kruta, tekuća i plinovita. To se postiže kombinacijom vrijednosti tlaka i temperature jedinstvene za svaku tvar (stabilnu u tim uvjetima) (Slika 2.). Trojna točka vode dogovorno je pri $273,16 \mathrm{~K}\left(0,01^{\circ} \mathrm{C}\right)$ i pri tlaku od $611,73 \mathrm{~Pa}[1,5,12]$. To je relativno nizak tlak, otprilike $1 / 166$ normalnog barometarskog tlaka na razini mora $(101325 \mathrm{~Pa})$. Tlak zasićene vodene pare pri određenoj temperaturi sličan je onome na Marsu. Ukoliko se razmotre električne osobine čiste vode, može se zaključiti kako je čista voda zapravo dobar izolator, odnosno slab vodič električne struje.

Međutim, budući da je voda izvrsno otapalo, uvijek se pronalazi trag otopine, najčešće soli. Čak i najmanja količina takvih nečistoća čini vodu vodljivom, budući da se te soli dijele na slobodne ione, koji svojim kretanjem provode struju. Molekule vode prirodno se disociraju na $\mathrm{H}^{+} \mathrm{i} \mathrm{OH}^{-}$ ione. Kad se krug zatvori, negativna elektroda (katoda) privlači $\mathrm{H}^{+}$ione, koji se na katodi neutraliziraju primanjem jednog elektrona i rekombiniraju $\mathrm{u}$ molekule vodika, $\mathrm{H}_{2}$. Istovremeno, pozitivna anoda, na kojoj se rekombinira u vodi kisik $\left(\mathrm{O}_{2}\right)$, privlači $\mathrm{OH}^{-}$ione. Plinovi, proizvodi elektrolize, izlaze na površinu u obliku mjehurića, gdje se mogu odvojeno sakupljati. Maksimalni specifični otpor vode iznosi $18,2 \mathrm{M} \Omega \cdot \mathrm{cm}$ pri $25 \mathrm{~S}$, što se dobro podudara s eksperimentalnim vrijednostima za ultra čistu vodu koja se koristi u laboratoriju ili u industriji poluvodiča $[5,13]$. 


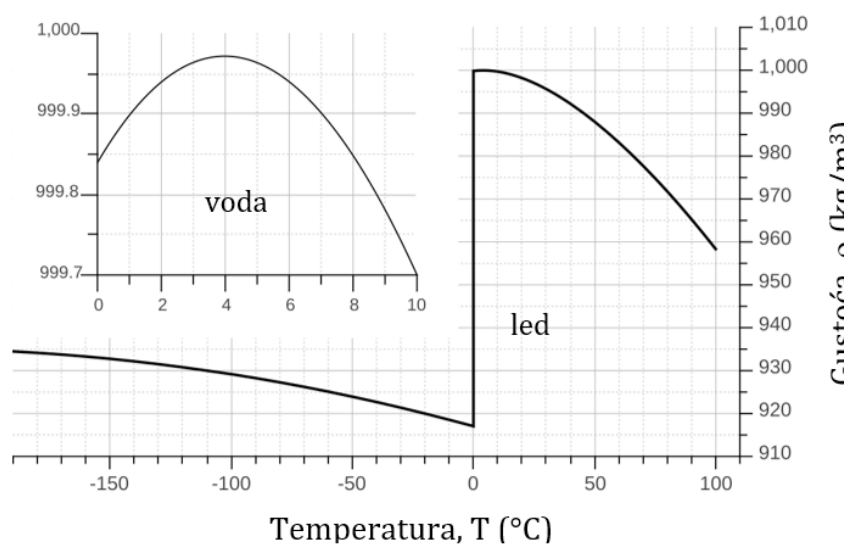

Slika 1. Gustoća leda i vode kao funkcija promjene temperature (modificirano prema [5])

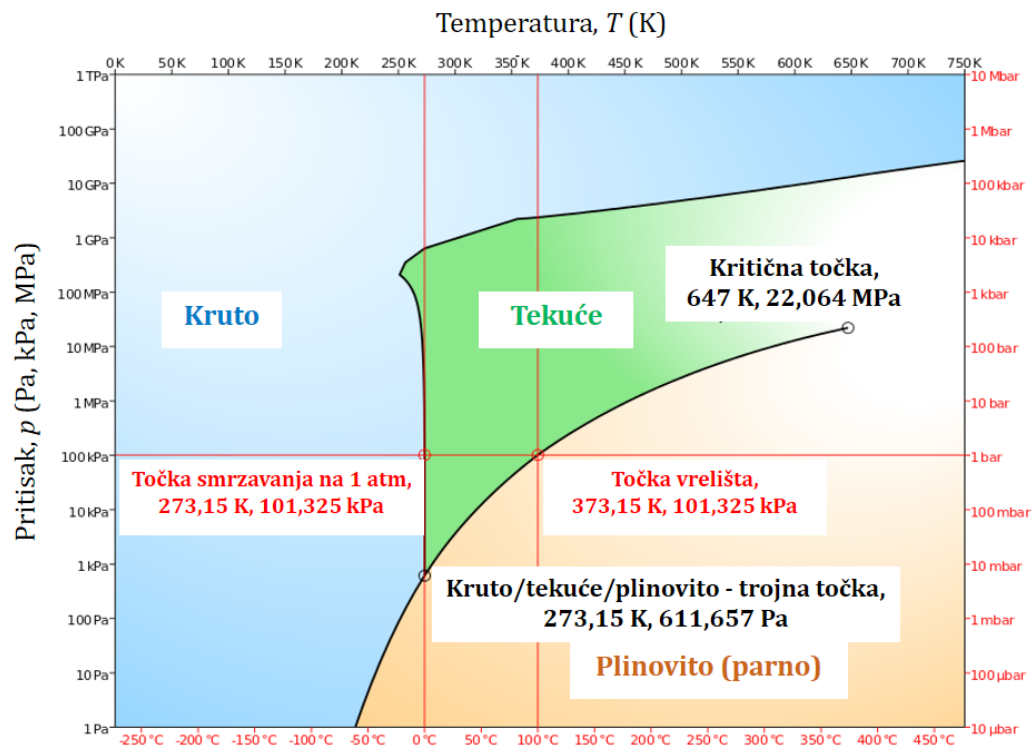

Slika 2. Trojna točka krutog/tekućeg/plinovitog stanja tekuće vode, leda i vodene pare u donjem lijevom dijelu dijagrama vodene faze (modificirano prema [5])

Vrlo važna značajka vode je njena polarnost, odnosno dipolna priroda. Molekula vode je kutnog oblika, gdje su atomi vodika pod kutom od 104,5 mjereno od središta atoma kisika. Kako je kisik elektronegativniji od vodika, molekula je na strani kisika nešto negativnija nego na vodiku, što dovodi do stvaranja električnog dipolnog momenta $[14,15]$. Suprotni naboji privlače i odbijaju molekule, što dovodi do dodatnih interakcija između molekula vode i drugih polarnih molekula. Vodikove veze među susjednim 
molekulama neprestano pucaju i ponovno se oblikuju (tipična veza ima životni vijek od nekoliko pikosekundi) [15]. Kohezivnost uvjetuje veliku površinsku napetost vode, kapilarnost, visoku točku vrelišta te specifičnu toplinu isparavanja. Zahvaljujući vodikovim vezama, voda je velikoga specifičnog toplinskog kapaciteta $\left(4185 \mathrm{Jkg}^{-1} \mathrm{~K}^{-1}\right)$, sa specifičnom toplinom

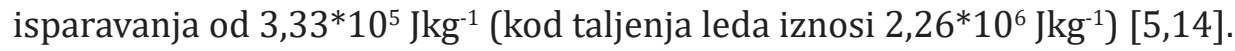
To znači da se prijelazom vodene pare u tekuću vodu, odnosno tekuće vode u led, oslobađa znatna energija, što omogućuje toplokrvnim organizmima održavanje temperature u potrebnim granicama (tzv. termoregulacija). Toplina isparavanja je kod vode visoka jer tijekom procesa mora doći do pucanja vodikovih veza. Ovo svojstvo vodu čini i izvrsnim rashlađivačem.

Zbog svoje polarnosti, voda je izvrsno otapalo. Kad se ionski ili polarni spojevi nalaze u vodi, molekule polarne vode grupiraju se oko čestice, iona ili molekula, čime neutralizira naboj iona ili molekula. Ovaj postupak „namotavanja“ molekula otapala oko otopine naziva se otapanje, a kad je u pitanju voda, hidratacija. Hidrirani ioni i molekule, uslijed neutralizacije izvornog naboja, više se ne privlače kao prije, izdvajaju se iz svoje kristalne rešetke (ili čiste tekuće faze) i prelaze u vodenu otopinu. Voda se miješa u svim omjerima s tvarima koje mogu disocirati, poput lužina, kiselina i soli $[1,2]$. Voda je amfoterna molekula, što znači da može pokazivati svojstva i kiselina i lužina. Pri pH=7 (neutralno stanje), koncentracija hidroksilnih iona $\left(\mathrm{OH}^{-}\right)$jednaka je koncentraciji hidronijevih iona $\left(\mathrm{H}_{3} \mathrm{O}^{+}\right.$) (odnosno vodikovih $\left(\mathrm{H}^{+}\right)$) iona. Ako se koncentracija navedenih iona promijeni, otopina postaje kiselija (pri porastu koncentracije hidronijevih, odnosno oksonijevih iona) ili lužnata (pri porastu koncentracije hidroksilnih iona) [2].

\section{Struktura molekula vode i priroda vodikovih veza u vodi}

Krajnje makroskopsko ponašanje vode ovisi o pojedinostima njezine molekulske strukture. Kvantna mehanika dopušta teorijsku analizu molekularne strukture iz poznavanja masa, naboja i spinova uključenih subatomskih čestica. Za to je potrebno rješenje Schrödingerove jednadžbe, čiji je Hamiltonijanov operator za molekulu vode dan kao $[1,16]$ :

$$
H=E_{n}+E_{e}+U(r, R)
$$

gdje prva dva termina na desnoj strani predstavljaju kinetičku energiju tri jezgre, odnosno 10 elektrona, dok je $U(r, R)$ funkcija potencijalne energije koja sadrži doprinose elektrostatičke interakcije iz svih parova čestica (koordinate čestica se prikazuju kao $r$ i $R$ ). Zbog velike razlike u masama jezgara i elektrona, prvi izraz u jednadžbi (1) malo pridonosi ukupnoj energiji. Adekvatno rješenje Schrödingerove jednadžbe može se dati razmatranjem elektroničkih gibanja u polju sila fiksnih jezgri. To je poznato 
kao Born-Oppenheimerova aproksimacija. Rješenje jednadžbe (1) slijedi uz konvencionalne linije, gdje se najprije moraju definirati elektronske vlastite vrijednosti i svojstvene funkcije. Iako za to ne postoji precizna metoda, dostupni su različiti približni tretmani za procjenu gornje granice energija elektrona $[1,7,17]$.

Rješenje nuklearne Schrödingerove jednadžbe daje informacije o unutarnjim gibanjima (vibracijama i rotaciji) molekule, a teoretski rezultati su u skladu s informacijama dobivenim infracrvenom spektroskopijom. Ravnotežna geometrija izolirane molekule vode $\left(\mathrm{H}_{2} \mathrm{O}\right)$ ukazuje da je duljina $\mathrm{O}-\mathrm{H}$ veze $0,0958 \mathrm{~nm}$, a kut kod $\mathrm{H}-\mathrm{O}-\mathrm{H}$ veze je $104^{\circ} 27^{\prime}[1,15]$. Glavne vibracije prikazane su na Slici 3. Ove frekvencije su modificirane u kondenziranim stanjima, gdje intermolekularni učinci postaju izuzetno važni. Atom kisika u Bjerrumovom modelu se nalazi u središtu regularnog tetraedra $\mathrm{s}$ frakcijama naboja $\pm \eta e$ smještenim u vrhovima tetraedra na udaljenosti od 0,1 nm od središta (Slika 4).

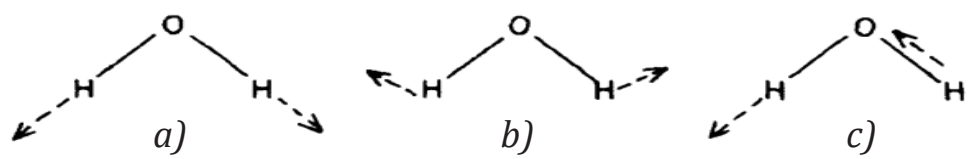

Slika 3. Tri glavne frekvencije vibracija molekule vode: (a) simetrično valentno istezanje $\left(v_{1}\right)$, (b) mod deformacije $\left(v_{2}\right)$, (c) asimetrično valentno istezanje $\left(v_{3}\right),[1]$

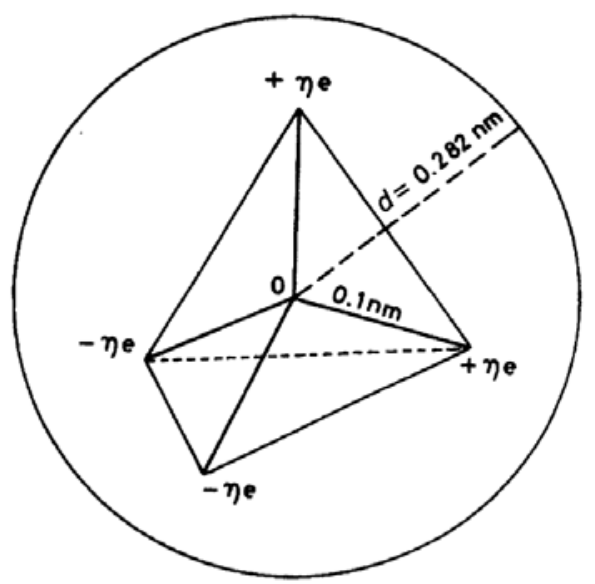

Slika 4. Bjerrumov model za vodu „s četiri točke punjenja“" (modificirano prema [1])

Van der Waalsov promjer (d), dodijeljen molekuli iznosi 0,282 $\mathrm{nm}[5,18]$. Prema tom prikazu, vrhovi koji nose pozitivni naboj su položaji dvaju atoma vodika, s dvije orbite parnih elektrona koje nose negativni naboj, usmjerene 
prema drugim dvjema točkama. Tijekom niza godina, izvorni Bjerrumov model strukture molekule vode „s četiri točke punjenja“ (Slika 4) podvrgnut je nekim poboljšanjima, a kako bi bio u skladu s kvantno-mehaničkim rezultatima, prema kojem molekula nije regularni tetraedar $[1,2]$.

\subsection{Pojam „dimer" vode}

U praksi je vrlo teško odrediti mjerodavnu $a b$ initio, odnosno početnu strukturu i svojstva izoliranih molekula vode jer je pritom otežano istraživanje interakcije između dvije ili više takvih molekula vode. Pritom se znanstvenici često bave sustavom od šest jezgri i 20 elektrona u kojima su molekule neizotropne kvadrupole ${ }^{1}$, tako da svaka interakcija vjerojatno sadrži značajne doprinose ovisne o orijentaciji. Da bi se došlo do realističnog opisa potencijalne površine energije dimera ${ }^{2}$ vode, potrebno je pozvati se na polu-empirijske metode. Prema Paulingovoj teoriji $[17,19]$, vodikova prva orbita može tvoriti samo jednu kovalentnu vezu, a svaka daljnja interakcija s donatorom elektrona mora biti elektrostatičke prirode. Međutim, moglo bi se očekivati da će se promjene raspodjele elektronske gustoće dogoditi kada se dvije polaribilne molekule približe jedna drugoj. Veliko izobličenje oblaka elektrona dovodi do tzv. delokalizacije energije, dok mali i koordinirani pomaci elektrona dovode do disperzije (Van der Waalsove) energije. Vrlo važna fizikalna veličina kod sagledavanja dimera vode je tzv. parna korelacija $g(r)$, koja određuje vjerojatnost pronalaženja atoma na udaljenosti $r$ od drugog atoma postavljenog na $r=0$. Položaj vrha označava najbližu udaljenost susjednih molekula, a površine vrha osiguravaju procjenu broja susjednih molekula unutar zadane udaljenosti (koordinacijski broj $n$ ). Voda ima $n=4,4$ (za led, $n=4$ ), tj. karakterizira povećanje, ekvivalentno kontrakciji krute tvari nakon taljenja [17]. Razmatranje položaja kisikovih atoma nije dovoljno za potpunu specifikaciju relativnih položaja dvije molekule vode u prostoru.

Imajući u vidu tetraedarsku strukturu dimera vode, takva potpuna specifikacija zahtijeva ugradnju uvjeta ovisnih o orijentaciji, tako da korelacijska funkcija mora biti zapisana kao $g(r, \Omega)$, gdje $\Omega$ predstavlja kutne koordinate (donora vodikove veze i kutove akceptora). Korelacijske funkcije $g_{\mathrm{O}-\mathrm{H}}(r)$ i $g_{\mathrm{H}-\mathrm{H}}(r)$ su nužno složenije od izgleda $g_{\mathrm{O}-\mathrm{O}}(r)$. Također ih je teže eksperimentalno mjeriti; s druge strane, samo poznavanje $g_{0-0}(r)$ ne daje dovoljno informacija za potpunu specifikaciju geometrije vodenog dimera

\footnotetext{
1 Kvadrupol (magnetski ili električni) je sustav dvaju dipola na maloj udaljenosti i jakoj interakciji, te je zbog toga njegovo djelovanje na okolinu bitno drugačije od djelovanja dvaju dipola. Niz pravilno razmještenih dipola može činiti multipol.

2 Dimeri (di- + -mer) su male molekule, niskomolekulski spojevi, koje se sastoje od dviju identičnih molekula ili dvaju identičnih monomera, povezane jakim ili slabim, kovalentnim vezama ili međumolekulskim silama. Dva dimera ulančavanjem tvore tetramer.
} 
$[1,20]$. Za mjerenje ili izračun $g(r)$ koriste se tri pristupa. Eksperimentalne metode oslanjaju se na rendgensko i neutronsko raspršivanje, dok teorijski pristupi pretpostavljaju znanje o funkciji potencijala molekularnog para $u(r)$. Gotovo sva teoretska istraživanja o dimerima vode u prošlosti su se oslanjala na računalne simulacijske pristupe, koji omogućuju izračunavanje strukturnih i dinamičkih svojstava iz pretpostavljenih potencijalnih funkcija. U mnogim predloženim metodama za „konstrukciju“ potencijalnih funkcija postoji opća suglasnost o energiji nuklearne disocijacije (20-35 kJ) i ravnotežnoj 0-0 vezi razdvajanja $(0,26-0,30 \mathrm{~nm})$, [21].

Dvije važne osobine vodikove veze su da posjeduje smjer i linearnost. Prema dogovoru, smjer H-veze je od kraće kovalentne veze do usamljenih parova susjednog atoma kisika (O-H .... O). To znači da atomi kisika djeluju kao akceptor H-veze sa svojim usamljenim parovima, a $\mathrm{H}$-atomi kao djelomični pozitivni naboji $(\delta+)$. Prema tome, $\mathrm{O}-\mathrm{H}$ atom vodika kovalentne veze donira se atomu kisika druge molekule vode, formirajući H-vezu. Linearnost H-veze znači da atom vodika općenito leži na istoj liniji koja povezuje dva atoma kisika [21]. Stoga je kut veze $0-\mathrm{H} 180^{\circ}$ u idealnoj H-vezi koja ima simetrični dvostruki minimalni potencijal (Slika 5).

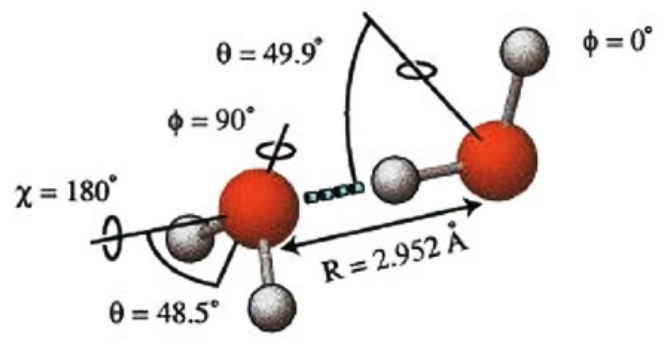

Slika 5. Ravnotežna struktura dimera vode (modificirano prema [22])

Nulta točka korigirane energije H-veze $\left(E_{H}\right)$ u dimeru vode je $4,85 \mathrm{kcal} /$ mol [22], a duljina O-H...O udaljenosti je $2,952 \AA$ A $\left(1 \AA=10^{-10} \mathrm{~m}\right)$. U tekućoj vodi, energija $\mathrm{H}$-veze može varirati u skladu s interpretacijom interakcije $\mathrm{H}$-veza. Pored toga, duljina i kut veze blago variraju s temperaturom [7]. Jačina H-veze u tekućoj vodi izračunava se na 1,32 kcal/mol [23].

\subsection{Vremenske skale molekularnih procesa u ledu i tekućoj vodi}

Prema Eisenbergu i Kauzmannu [7], voda ima trenutnu (I), vibracijsku (V) i difuzijsku (D) strukturu, koja odgovara različitim vremenskim domenama promatranja (Slika 6). Oznake $\tau_{D}$ i $\tau_{v}$ na Slici 6 predstavljaju razdoblja molekularnog pomaka i oscilacija. $\tau_{s}$ je razdoblje za $\mathrm{O}-\mathrm{H}$ vibraciju istezanja, dok je $\tau_{E}$ vrijeme koje je potrebno da jedan elektron 
završi jedan krug u najužoj Bohrovoj orbiti. Vodoravne crte ispod vremenske skale prikazuju vremenske intervale za koje su različite eksperimentalne tehnike davale informacije o ledu i vodi.

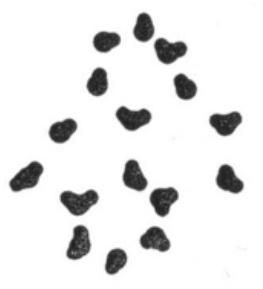

I-struktura

(a)

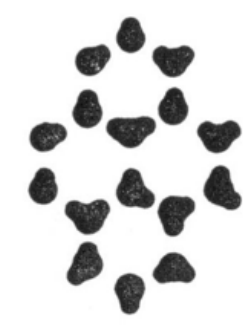

V-struktura

(b)

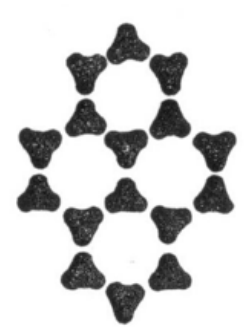

D-struktura

(c)

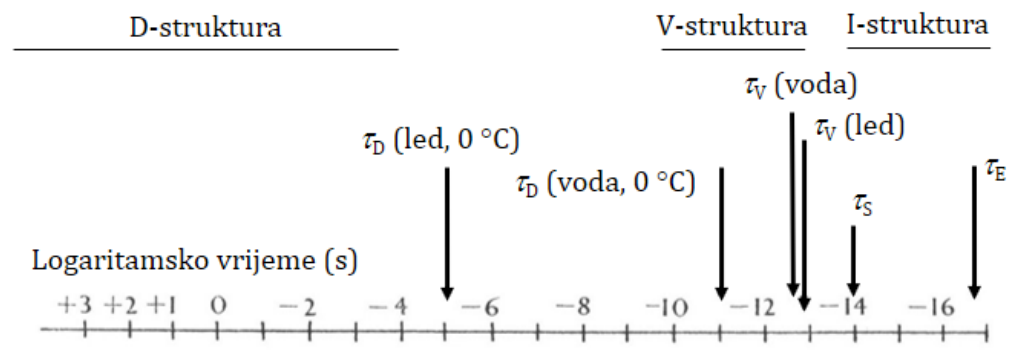

Rentgenska difrakcija

$\stackrel{\text { Rentgenska difrakcija }}{\longleftarrow}$ NMR kemijski pomak

Termodinamička svojstva

Raspršenje svjetlosti
Dielektrično opuštanje

neelastično raspršivanje neutrona Infracrvena + Ramanova spektroskopija

Ultrazvučna apsorpcija

Slika 6. Prikaz trenutne (I), vibracijske (V) i difuzione (D) strukture leda i vremenske skale molekularnih procesa u ledu i tekućoj vodi (modificirano prema [7])

Orijentacije molekula u I-strukturi rezultat su nasumičnih vibracijskih pokreta. Osrednjavanje vibracijskih pokreta u kratkoročnom mjerilu dovelo bi do snimanja tetraedarskog rasporeda molekula vode. To se naziva V-strukturom. Kod duljih perioda vremena dobiva se difuzijska prosječna D-struktura. I-struktura vode istražena je u studiji apsorpcije rendgenskih zraka [24]. Ova metoda uključuje pobuđivanje jezgre elektrona od vodene molekule do nezauzetih molekularnih orbitala u valentnoj ljusci. Energije, potrebne za takva pobuđenja, osjetljive su na lokalno okruženje molekula vode tijekom životnog vijeka elektroničke pobude $\left(<10^{-15} \mathrm{~s}\right)$. Stoga ova metoda daje informacije o trenutnom strukturiranju vode $\mathrm{u}$ 
subtemptosekundnim vremenskim razmjerima [25]. Prema provedenim istraživanjima može se zaključiti da $80 \%$ molekula vode obične tekuće vode ima jednu snažnu i jednu slabo vezanu O-H skupinu. Preostalih $20 \%$ je tetraedralno koordinirano. V-struktura tekuće vode ispituje se infracrvenom i Ramanovom spektroskopskom metodom [18], kao i eksperimentima rasipanja rendgenskih zraka i neutrona [26,27]. Ovi eksperimenti otkrili su da postoji kratak raspon lokalnog reda oko središnje molekule u tekućoj vodi, što nalikuje lokalnoj tetraedarskoj strukturi u ledu. Do ovog rezultata se može doći usporedbom funkcija radijalne raspodjele (eng. radial distribution function - rdf) tekuće vode i leda i u velikoj mjeri uočiti podudaranje položaja vrhova. Pored strukturnih istraživanja, termodinamička i transportna svojstva tekuće vode, koja su povezana $\mathrm{s}$ D-strukturom, proučavana su kroz širok raspon tlaka i temperature $[7,28]$. Procesi opuštanja povezani s dinamikom vode poznati su kroz dielektrične tehnike opuštanja u kojima se formuliraju termodinamičke funkcije $g(T, p)$, odnosno osnovne jednadžbe stanja, a kako bi se izračunala termodinamička svojstva tekuće vode. U suštini, D-struktura se uzima kao prostorni prosjek svih lokalnih V-struktura koje su istodobno prisutne u tekućini. U tom pogledu se funkcija radijalne raspodjele vode tretira kao prosjek radijalnih funkcija raspodjele za nekoliko V-struktura te se na taj način prosječni broj najbližih susjeda može izračunati iz područja ispod prvog vrha krivulje radijalne raspodjele. Na temelju eksperimenata s difrakcijom rendgenskih zraka otkriveno je da se lokalni red u tekućoj vodi pri sobnoj temperaturi ne proteže dalje od druge koordinacijske ljuske susjednih molekula. Ujedno je otkriveno da se funkcije radijalne raspodjele postupno mijenjaju s temperaturom, pri čemu se redoslijed kratkog dosega proširuje na manje udaljenosti pri porastu temperature.

Razvoj računalne tehnike omogućio je proučavanje molekularne dinamike (MD) da postane popularni alat za istraživanje strukture i dinamike tekuće vode. Danas je u svijetu razvijen veliki broj vodenih potencijala (više od 40), koji se koriste za opisivanje interakcije između parova molekula vode u simulaciji molekularne dinamike [25]. Vrijedne informacije kroz studije MD-a dovele su do saznanja o preuređivanju H-veza, dinamici oštećenja i procesima relaksacije u tekućoj vodi.

Procjena eksperimentalnih podataka o termodinamičkim svojstvima tekuće vode i interpretacija fizičkih svojstava u odnosu na njezinu strukturu zahtijevaju adekvatne modele vode. U tom pogledu je do sada uveden veliki broj modela vode koji se mogu podijeliti u dvije široke kategorije: a) modele izobličene vodikove veze ili kontinuuma i b) modele smjese (tzv. miješani modeli ili međuprostorni modeli). Prema modelima kontinuuma, H-veze se nikada ne razbijaju u tekućini pa su ovi modeli vrlo bliski čvrstom stanju. Krutost ovih modela čini ih nedovoljnima za uspješno objašnjavanje svih fizikalnih i termodinamičkih svojstava tekuće vode $[5,8,25]$. Jedna 
od pretpostavki ovakvih modela je da strukturiranje vode prevladava različite geometrije u slučajno-strukturiranoj mreži tekuće vode, ovisno o temperaturi. Ravnotežni pomaci u dominantnim strukturama pripisuju se promjeni duljine vodikove veze i energije kao funkcije temperature.

Kod modela smjesa, zajedničko stajalište znanstvenika jest da se voda sastoji od dobro uređenih komponenti sličnih ledu i drugih komponenti manje uređenosti. Osnovna razlika između modela smjese i kontinuuma je u tome što modeli smjesa dopuštaju prisutnost netaknutih i razbijenih vodikovih veza. Postoje različiti formalizmi modela smjesa prema tumačenju ledenih i gustih struktura vode. Jednu od njih dali su Nemethya i Scheragae [23] u svom statističkom termodinamičkom modelu za opisivanje termodinamičkih svojstava tekuće vode. Oni su pretpostavili da se voda sastoji od "malih, gotovo sfernih" nakupina, koji uglavnom imaju tridimitnu strukturu i nepovezanih molekula vode, koji ispunjavaju prostor između sfernih klastera. Prema ovoj modifikaciji, unutrašnjost klastera sadrži molekule vode koje imaju četiri vodikove veze, dok se na rubovima klastera mogu naći jedna, dvije i tri vodikove veze.

Ukoliko se osvrnemo na suvremene teorije o strukturi tekuće vode, modeli kontinuuma i smjese se neprestano modificiraju i poboljšavaju te favoriziraju eksperimentalne podatke o svojstvima vode. Na temelju dosadašnjih spoznaja o strukturi i ponašanju tekuće vode, postoje dva krajnja pogleda na model kontinuuma i smjese. Primjera radi, ukoliko se vrše mjerenja poput eksperimenata raspršivanja neutrona (dizajnirana za ispitivanje prosječne mikroskopske strukture tekuće vode), tada će se bolje pokazati primjena modela kontinuuma, dok će se termodinamička mjerenja fluktuacija pojedinih fizikalnih veličina vode (npr. stlačivosti ili toplinskog kapaciteta) bolje opisati modelima smjese.

Razvojem eksperimentalnih tehnika i metodologija danas je moguće prikupiti pouzdane podatke o strukturi pregrijane tekuće vode. Na temelju trenutnih eksperimentalnih podataka, predlaže se da se tekuća voda sastoji od područja niske gustoće (eng. low-density liquid, $L D L$ ) u kojoj dominiraju dobro uređene ledene strukture i područja visoke gustoće (eng. highdensity liquid, $H D L$ ), koje imaju manje uređenu strukturu (uglavnom imaju intersticijske molekule vode), $[5,8]$. Prisutnost ovih područja s različitim gustoćama u podhlađenoj tekućoj vodi također je otkrivena pokusima X-zraka i raspršivanjem neutrona.

\section{Dodatna razmatranja fizikalnih svojstava vode}

Postoji nekoliko prijepora koji su svojstveni formulaciji molekulskog opisa tekućine. S jedne strane, možemo ju sagledavati kao gustu, kristalnu krutinu u kojoj atomi ili molekule zauzimaju zadane položaje u prostoru 
i gdje je jedino moguće oscilatorno gibanje, centrirano oko ravnotežnih položaja. Tekućina se tada može smatrati perturbiranom čvrstom tvari u kojoj je stupanj reda smanjen pri taljenju, pri čemu se naglasak i dalje stavlja na položaje koje zauzimaju molekule tijekom vremenskog prosjeka $[5,7,15]$. S druge strane, tekućina se može razmatrati kao razrijeđeni plin u kojem se molekule mogu slobodno kretati nasumičnim putem i ne djeluju međusobno (ne zauzimaju poželjne položaje u odnosu jedna na drugu). Tekućina se tada smatra gustim plinom, u kojem je difuzno gibanje još uvijek važno, premda inhibirano blizinom drugih molekula i podvrgnuto značajnom stupnju molekularne interakcije $[1,2,15]$. Oba pristupa imaju svoje prednosti, iako je razvoj tehnika rendgenske i neutronske difrakcije stavio naglasak na čvrsta svojstva (tj. strukturu tekućina).

Tekućine se mogu klasificirati prema prirodi uključenih intermolekularnih sila. Ove interakcije određuju izgled P-V-T dijagrama (dijagram tlaka-volumena-temperature) koegzistencije faza, koji je stoga karakterističan za određenu tvar. Slika 7 predstavlja P-T projekciju dijela visokog tlaka faznog dijagrama za vodu. U superkritičnom području, pri danom tlaku, gustoća i temperatura mogu se neovisno mijenjati. Primjerice, pri temperaturi od $500{ }^{\circ} \mathrm{C}$, voda se može komprimirati do gustoće od $2,1^{*} 10^{3} \mathrm{kgm}^{-3}$. Podaci o fazi visokog tlaka imaju veliku važnost u projektiranju elektrana, kontroli korozije i geokemiji [1]. Vjerojatno najnormalnije svojstvo tekuće vode je njen veliki toplinski kapacitet, koji se smanjuje na polovicu vrijednosti nakon zamrzavanja ili ključanja. Taj iznimno veliki toplinski kapacitet igra važnu ulogu u održavanju klimatskog okruženja u kojem život može postojati (primjer Golfske struje). Dok P-V-T dijagram ponašanja (tekuće) vode možda nije tipičan za malu molekulu, njezina transportna svojstva pokazuju manje ekscentričnosti.

Praktično poznavanje svojstava gustoće vode, volatilnosti i viskoznosti prethodilo je razvoju znanstvenog razumijevanja. Danas, svojstva vode igraju ključnu ulogu, npr. u oceanografiji i limnologiji, hidraulici, biokemiji i fizikalnoj kemiji. Obično su termodinamička i transportna svojstva od najveće praktične važnosti. Za mnoge primjene vrijednosti svojstava potrebna je velika preciznost, iako njihov odnos prema strukturi na molekularnoj razini još uvijek može biti nesavršeno shvaćen $[29,30]$. 


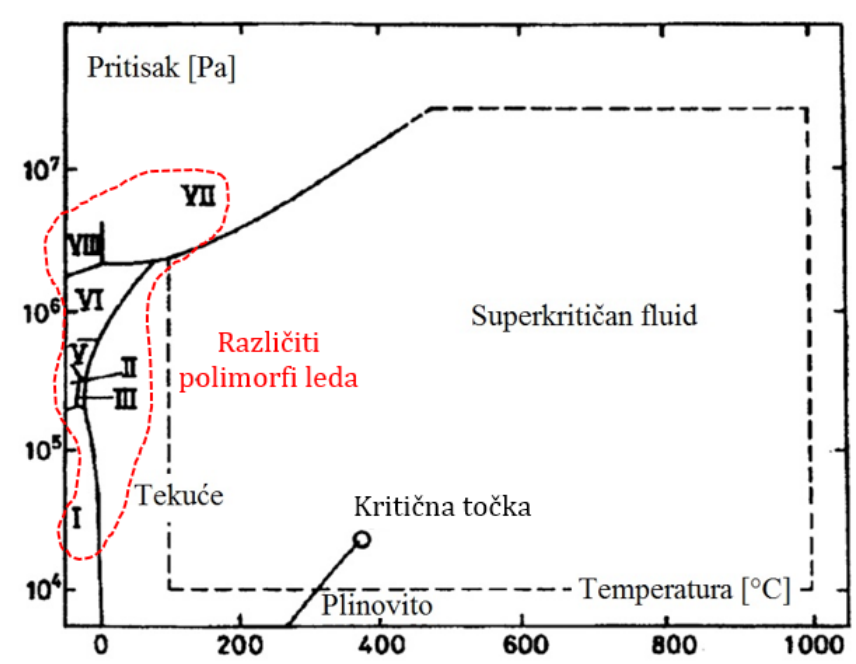

Slika 7. P-T projekcija visokotlačnog dijela faznog dijagrama vode (modificirano prema [1])

Gustoća je važna za većinu drugih istraživanja vode. Stoga je ona predmet brojnih mjerenja, posebno u temperaturnom rasponu od 0 do $40{ }^{\circ} \mathrm{C}$, gdje su učinjena brojna opsežna istraživanja. Kao i volumen pri atmosferskom tlaku, izotermalna kompresibilnost $\left(\kappa_{T}\right)$ prikazuje minimum, u ovom slučaju blizu $46,5^{\circ} \mathrm{C}$. Omiljena metoda za mjerenje $\kappa_{T}$ je brzina zvuka, koja se može odrediti s visokim stupnjem preciznosti. Za brzinu samog zvuka $u$, tj. za $(\partial \rho / \partial P)_{S}$, ekstrem je na $74{ }^{\circ} \mathrm{C}$, za izentropsku kompresibilnost, $\kappa_{S}=-\left[(\partial(\ln V) / \partial P)_{S}\right]$, to je $64^{\circ} \mathrm{C}$, a za $\left.(\partial V) / \partial P\right)_{\mathrm{T}}$ to je $42,3{ }^{\circ} \mathrm{C}$, a sve se to razlikuje od $46,5^{\circ} \mathrm{C}$ za $\kappa_{T}[1,5,30]$. Postojanje ovih temperatura povezano je $\mathrm{s}$ fenomenom maksimalne gustoće, ali je jasno da ne postoji jedna temperatura iznad koje se voda ponaša kao normalna tekućina i ispod koje je ona svojstvena. Pri atmosferskom tlaku, temperatura maksimalne gustoće, tj. temperatura na kojoj vrijedi iznosi $3,98^{\circ} \mathrm{C}$. Pri višim tlakovima, maksimalna gustoća se seli na niže temperature, s ovisnošću koja se definira kao [1]:

$$
\left(\frac{\partial T}{\partial P}\right)_{\rho \max }=-\frac{\left[\left(\frac{\partial}{\partial T}\right)\left(\frac{\partial \rho}{\partial P}\right)_{T}\right]_{P}}{\left(\frac{\partial^{2} \rho}{\partial T^{2}}\right)_{P}}
$$

Formula slijedi iz temperaturne ovisnosti stišljivosti i toplinskog širenja te je utvrđeno da je $\left(\frac{\partial T}{\partial P}\right)_{\rho \max }=-0,0200 \pm 0,0003^{\circ} /$ baru. Ova linija doseže ravnotežnu liniju led-tekućina pri $-4{ }^{\circ} \mathrm{C}$ i tlaku od 400 bara. Za deuterij 
$\left(D_{2} \mathrm{O}\right)$ u teškoj vodi odgovarajuća vrijednost iznosi - 0,0178 \% baru. Položaj ove linije je mjera osobitosti tekuće vode, a kod deuterija ne samo da je viša od atmosferskog tlaka $\left(11,44^{\circ} \mathrm{C}\right.$ u odnosu na $\left.3,98{ }^{\circ} \mathrm{C}\right)$, već se ne povećava na niže temperature s povećanjem tlaka.

Slika 8 prikazuje stabilno područje na temperaturama do kritične točke. Mogu se razlikovati tri opća područja. Na nižim tlakovima, u blizini kritične točke, ponašanje je kod visokih tlakova (pri 10 kbar) vrlo uobičajeno, a pri niskim temperaturama i tlakovima mogu se naći posebne osobine vode, kao što je minimalna stišljivost i maksimalna gustoća. Pri nižim tlakovima, tekućina se može akomodirati pri većim volumenima, što je posljedica manje deformacije intermolekularnih kutova. Tekuća voda je $10 \%$ gušća od običnog leda tipa Ih. Međutim, difrakcija rendgenskih zraka i infracrveni spektar pokazuju da je kod vodikove veze među molekulama vode udaljenost između dva atoma kisika oko 2,8 $\AA$ (dok Van der Waalsov radijus kisika iznosi $r_{0}=1,5 \AA$ ) [7,8,11].

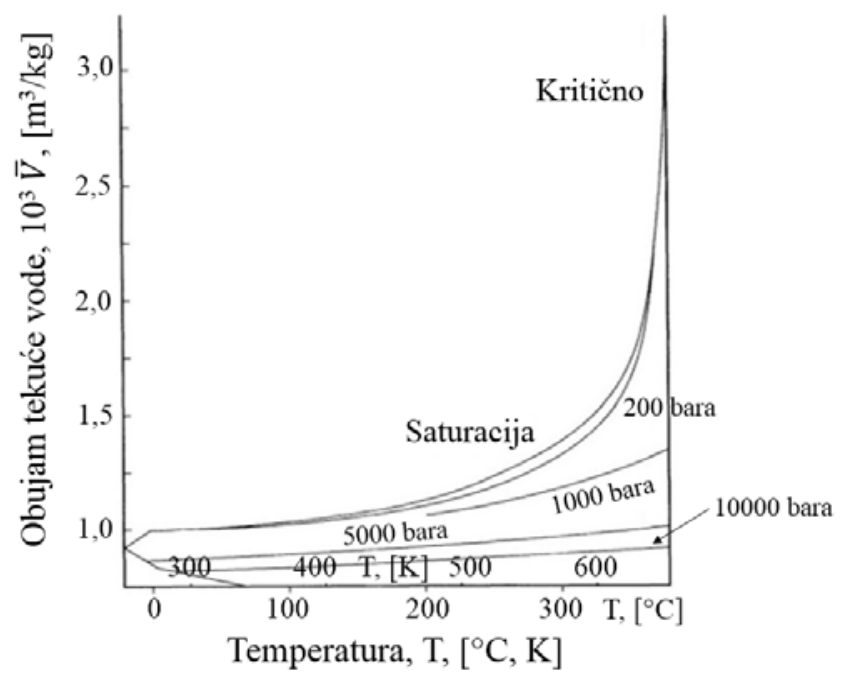

Slika 8. Obujam tekuće vode kao funkcija temperature (polje se završava donjim lijevim krivuljama raznih ledenih polimorfa), (modificirano prema [1])

Voda zbog visokog vrelišta postoji pretežno u tekućem obliku u rasponu okruženja u kojima „cvjeta“ život, iako ostale dvije faze, led i para, igraju ključnu ulogu u oblikovanju okoliša. Visoka specifična toplina i toplina isparavanja vode imaju važne posljedice za organizme na staničnoj i fiziološkoj razini, posebno za učinkovitost procesa koji uključuju prijenos topline, regulaciju temperature, hlađenje i slično. Viskoznost je glavni parametar vode, koji određuje kako se brzo molekule i ioni mogu transportirati i koliko brzo difundiraju u vodenoj otopini $[1,9]$. Na taj način 
se pruža gornja tjelesna granica stope mnogih događaja na molekularnoj razini, unutar kojih organizmi moraju živjeti i razvijati se. Visoka površinska napetost vode bitna je sa dva aspekta gledanja. Prvo, ispod skale duljine od oko $1 \mathrm{~mm}$ sile površinske napetosti dominiraju gravitacijskim i viskoznim silama, a sučelje zrak-voda postaje djelotvorno neprobojna prepreka. To postaje glavni čimbenik u okolišu i načinu života malih insekata, bakterija i drugih mikroorganizama. Drugo, na molekularnoj skali $(0,1-100 \mathrm{~nm})$ površinska napetost igra ključnu ulogu u svojstvima otapala u vodi $[1,8]$. Velika dielektrična konstanta vode također igra važnu ulogu u njenom djelovanju kao otapalo. Biološki značaj širenja vode nakon hlađenja ispod $48{ }^{\circ} \mathrm{C}$ i zamrzavanja uglavnom je neizravan kroz geofizičke aspekte kao što su smrzavanje oceana i jezera, formiranje polarne ledene kape i vremenski utjecaj u ciklusima smrzavanja-otapanja.

Voda kao otapalo može otopiti nevjerojatnu raznolikost važnih molekula, u rasponu od jednostavnih soli do malih molekula poput šećera i metabolita, do vrlo velikih molekula poput proteina i nukleinskih kiselina. Praktično svi molekularni procesi bitni za život (npr. kemijske reakcije, udruživanje i vezivanje molekula, difuzijski procesi, ionski procesi i sl.) pod direktnim su utjecajem djelovanja vode i njezinog djelovanja u svojstvu otapala.

\section{Zaključak}

Među kemijskim tvarima, voda je jedinstvena u mnogim aspektima, unatoč prividnoj molekulskoj jednostavnosti. Poznati nobelovac A. SzentGyörgy nazvao je vodu "matricom života“. Razvoj tehnike rasipanja neutrona dovelo je do mnogo boljeg uvida u prirodu tzv. hidratacijskih interakcija te do korisnog testiranja modela hidratacije, dobivenih računalnom simulacijom ili „ab initio“ teoretskim pristupima. Slično tome, moderne tehnike spektroskopije omogućile su detaljnu studiju uloge vode u promicanju i održavanju složenih bioloških struktura. Postignut je slabi napredak u razvoju poboljšanog kvantitativnog opisa za tekuću tvar na molekularnoj osnovi. Također, postoji složenost molekule vode (tri jezgre i 10 elektrona), koja isključuje stroge „ab initio“ pristupe. Postoji mnoštvo potencijalnih funkcija za dimer vode, od kojih nijedna nije potpuno zadovoljavajuća.

Računalna simulacija trenutno je najpopularnija metoda za proučavanje složenih vodenih sustava. Simulacija je moćan alat, no treba biti na oprezu prije nego što se prihvate rezultati takvih izračuna, osobito ukoliko ih se ne može eksperimentalno testirati. Međumolekularna priroda vode, koja je postala predmet proučavanja u ranim godinama 20. stoljeća, sredinom tog stoljeća dosegla je svoj vrhunac. Istraživanja „strukture vode“ značajno 
su napredovala posljednjih 15-tak godina, no i dalje postoji udio pogrešnih tumačenja.

Ranije pionirske studije o nedovoljno ohlađenoj vodi ukazale su na očitu singularnost pri $-45{ }^{\circ} \mathrm{C}$, koju karakterizira divergencija većine fizikalnih svojstava. Ovaj fenomen je dao daljnji poticaj istraživanju pothlađene vode, posebno kada je povezan sa spoznajom da se tekuća voda može prevesti u amorfnu krutinu. Iako vjerojatno nije od neposredne praktične važnosti, osigurava se budućnost istraživanja nestabilne vode na niskim temperaturama i/ili visokim tlakovima.

Krajem 20. stoljeća znanstvenici su smatrali da bi superkritična voda (slično kao i superkritični ugljični dioksid) mogla imati svijetlu budućnost u kemijskoj obradi. Njezina izvanredna svojstva otapala i nepostojanje opasnosti od onečišćenja okoliša bi superkritičnu vodu trebala učiniti pogodnim otapalom za kemijske procese. Stručne studije izvedivosti postoje, a primjer je depolimerizacija celuloznog otpada u glukozu. Taj se proces može provesti vrlo brzo (bez zagađenja), no treba reći da visoka temperatura i tlak, potrebni za takve procese, vjerojatno nadmašuju bilo kakve prednosti.

Voda je glavni sastojak svih živih bića. Jedinstvena je po mnogim svojim fizikalnim i kemijskim svojstvima. Neka su bitna za život, dok druga svojstva imaju duboke učinke na veličinu i oblik živih organizama, način njihovog rada i ograničenja unutar kojih moraju djelovati. Mnoga osnovna fizikalna svojstva vode se prema dosadašnjim istraživanjima mogu objasniti, makar polukvalitetno, u molekularnom i strukturalnom smislu, iako uprkos intenzivnom proučavanju, ostaje mnogo otvorenih pitanja. Brzi razvoj fizikalnih (eksperimentalnih) i računalnih metoda trajno donosi nove informacije o finim karakteristikama strukture i dinamike ove izvanredne tvari.

\section{Literatura}

[1] Franks, F. (2000) Water: A Matrix of Life. The Royal Society of Chemistry, Cambridge CB4 OWF, United Kingdom

[2] Ball, P. (2008) Water - an Enduring Mystery. Nature, 452 (7185), pp. 291292.

[3] Franks, F. (1998) The Hydrologic Cycle, in Handbook of Water Purification, ed. M. Gross, Life on the Edge, Plenum Press, New York.

[4] Rahman, A., Stillinger, F. (1971) Molecular Dynamics Study of Liquid Water. Journal of Chemical Physics, 55, pp. 3336-3359.

[5] Properties of Water, https://en.wikipedia.org/wiki/Properties_of_water, (pristupljeno 27.5.2020.) 
[6] Henderson, LJ. (1913) The Fitness of the Environment: An Inquiry in to the Biological Significance of the Properties of Matter. New York: Macmillan.

[7] Eisenberg, D., Kauzmann, W. (1969) The Structure and Properties of Water. Oxford: Oxford University Press.

[8] Malenkov, G.G. (2006) Structure and Dynamics of Liquid Water. Journal of Structural Chemistry, 47, Supplement, pp. S1-S31.

[9] Laws, R.M., Franks, F. (1993) Life at Low Temperatures, Phil. Princeton University Press, Princeton, New York.

[10] Water, II(3). Hobbs, P.V. (1975) Ice Physics, Oxford University Press, Oxford

[11] Sharp, K.A. (2001) Water: Structure and Properties. Encyclopedia of life sciences, John Wiley \& Sons, Ltd., pp. 1-7.

[12] Feistel, R., Wagner, W. (2005) High-Pressure Thermodynamic Gibbs Functions of Ice and Sea Ice. Journal of Marine Research, 63, 1, pp. 95-139.

[13] Bernel, J.D., Fowler, R.H. (1933) The Structure of Water. J. Chem. Phys., 1, 515.

[14] Bowron, D.T., Filipponi, A., Roberts, M.A., Finney, J.L. (1998) Hydrophobic Hydration and the Formation of Clathrate Hydrates, Phys. Rev. Lett., 81, 4164.

[15] Kajiwara, K., Franks, F., Echlin, P., Greer, A.L. (1999) Structural and Dynamic Properties of Crystalline and Amorphous Phases in Raffinose-Water Mixtures, Pharm. Res., 16, 1441.

[16] Hoy, A.R., Bunker, P.R. (1979) A Precise Solution of the Rotation Bending Schrödinger Equation for a Triatomic Molecule with Application to the Water Molecule. Journal of Molecular Spectroscopy, 74, 1, pp. 1-8.

[17] Pauling, L. (1959) The Hydrogen Bonding, D. Hadji (ed.), London, pp. 1-6.

[18] Bakker, H.J., Lock, A.J., Madsen, D. (2004) Strong Feedback Effect in the Vibration Relaxation of Liquid Water, J. Chem. Phys., Lett. 384, pp. 236-241.

[19] Water, I (1,2,3). Finney, J.L., Quinn, J.E., Baum, J.O. (1985) The Water Dimer Potential Surface. Water Sci. Rev., 1, 93

[20] Angell, A. (1982) Water. A Comprehensive Treatise, 7, F. Franks (ed.), Plenum, New York.

[21] Chaplin M. (2007) Models for Water. http://www.lsbu.ac.uk/water/models.html, (pristupljeno 18.4.2020).

[22] Keutsch, F.N., Saykally, R.J. (2001) Water clusters: Untangling the Mysteries of the Liquid, One Molecule at a Time, Proceedings of the National Academy of Sciences of the USA, PNAS, 98, 19, pp. 10533-10540.

[23] Nemethy, G., Scheraga, H.A. (1962) Structure of Water and Hydrophobic Bonding in Proteins. I. A Model for the Thermodynamic Properties of Liquid Water, J. Chem. Phys., 36, 3382, https://doi.org/10.1063/1.1732472

[24] Wernet, P., Nordlund, D., Bergmann, U. (2004) The Structure of the First Coordination Shell in Liquid Water, Science, 304, 995.

[25] Chaplin M. (2007) Hydrogen Bonding in Water. http://www.lsbu.ac.uk/water/hbond.html\#d, (pristupljeno 20.5.2020). 
[26] Bellissent-Funel, M.C., Bosio, L. (1995) A Neutron Scattering Study of Liquid $\mathrm{D}_{2} \mathrm{O}$ under Pressure and at Various Temperatures, J. Chem. Phys., 102, 3727. https://doi.org/10.1063/1.468555

[27] Soper, A.K., Bruni, F., Ricci, M.A. (1997) Site-Site Pair Correlation Functions of Water from 25 to $400{ }^{\circ} \mathrm{C}$ : Revised Analysis of New and Old Diffraction Data, J. Chem. Phys., 106, pp. 247-254, https://doi.org/10.1063/1.473030

[28] Debenedetti, P.G. (2003) Supercooled and Glassy Water, J. Phys.: Condens. Matter, Vol. 15, No. 45, pp. 1669-1726, https://doi.org/10.1088/09538984/15/45/R01

[29] Kelly, R.M., Baross, J.A., Adams, M.W.W. (1994) Life in Boiling Water, eds. Wallace, L., Bernath, P., Livingston, W., Hinkle, K., Busler, J., Guo, B. and Lorch, W., McGraw-Hill, London, Chem. Britain, July, 555.

[30] Franks, F. (1997) Phase Changes and Chemical Reactions in Solid Aqueous Solutions: Science and Technology“, Pure Appl. Chem., 69, 915. 
